\title{
LONG MEMORY IN RETURNS AND INTEGRATION: THE GASE OF EMERGENT STOCK MARKETS
}

\author{
Anita TODEA ${ }^{\mathrm{a} *}$ \\ a) Babeș-Bolyai University, Faculty of Economics and Business Administration, \\ Cluj-Napoca, Romania
}

Please cite this article as:

Article History:

Todea, A., 2018. Long memory in returns and Received: 20 January 2018 integration: the case of emergent stock markets. Accepted: 10 April 2018 Review of Economic Studies and Research Virgil Madgearu, 11(1), pp.97-113.

doi: 10.24193/RVM.2018.11.23.

Abstract: This paper presents empirical results suggesting that stock markets integration had a positive impact on the informational efficiency of twenty emergent stock markets during the period 1999-2013. The Generalized Hurst exponent assesses the efficiency, while integration is measured by the explanatory power of a number of global factors for the individual country's stock market returns. Additionally, we have noticed that during the global crisis, while stock market integration is increasing, the phenomenon of persistence in returns tends to manifest itself with greater intensity. Despite this, the more integrated markets are the least affected in terms of efficiency. This result supports the positive effect of financial liberalization even during the turbulent periods of financial crisis.

Key words: informational efficiency; market integration; Hurst exponent; global financial crisis; emergent stock markets

JEL Classification: $C_{13}$; G14; G15

(C) 2018 Alma Mater Publishing House. All rights reserved.

* Corresponding author. E-mail address: anita.todea@econ.ubbcluj.ro. 


\section{References}

1. Albuquerque, R., Bauer, G.H. and Schneider, M. 2009. Global private information in international equity markets. Journal of Financial Economics, 94, pp.18-46.

2. Bae, K.H. and Zhang, X., 2015. The cost of stock market integration in emerging markets. Asia-Pacific Journal of Financial Studies, 44(1), pp.1-23.

3. Bae, K.H., Ozoguz, A., Tan, H. and Wirjanto, T.S., 2012. Do foreigners facilitate information transmission in emerging markets? Journal of Financial Economics, 105, pp.209-227.

4. Barabasi, A.L. and Vicsek, T., 1991. Multifractality of self-affine fractals. Physical Review A, 44, pp.2730-2733.

5. Barunik, J. and Kristoufek, L., 2010. On Hurst exponent estimation under heavy-tailed distributions. Physica A, 389, pp.3844-3855.

6. Bekaert, G. and Harvey, C., 2017. Emerging Equity Markets in a Globalizing World”. Available at: SSRN: https://ssrn.com/ abstract $=2344817$.

7. Berger, T. and Pozzi, L., 2013. Measuring time-varying financial market integration: an unobserved components approach. Journal of Banking \& Finance, 37, pp.463-473.

8. Cajueiro, D.O. and Tabak, B.M., 2004. Ranking efficiency for emerging markets", Chaos, Solitons and Fractals, 22, pp.349-352.

9. Dacorogna, M., Muller, U., Olsen, R. and Pictet, O., 2001. Defining efficiency in heterogeneous markets. Quantitative Finance, 1(2), pp.198-201.

10. Di Matteo, T., Aste, T. and Dacorogna, M., 2005. Long-term memories of developed and emerging markets: Using the scaling analysis to characterize their stage of development. Journal of Banking and Finance, 29, pp.827-851.

11. Eom, C., Choi, S., Oh, G. and Jung, W.S., 2008. Hurst exponent and prediction based on weak-form efficient market hypothesis of stock markets. Physica A, 387, pp.4630-4636.

12. Frijns B., Margaritis D. and Psillaki M., 2012. Firm efficiency and stock returns. Journal of Productivity Analysis, 37, pp.295-306.

13. Gu, R., Shao, Y. and Wang, Q., 2013. Is the efficiency of stock market correlated with multifractality? An evidence from the Shanghai stock market. Physica A, 392, pp.361-370. 
TODEA, LONG MEMory IN RETURNS ANd INTEGRATION...

14. Hasan, R. and Salim, M.M., 2015. Multifractal analysis of Asian markets during 2007-2008 financial crisis. Physica A, 419, pp.746-761.

15. Hooy, C.W. and Lim, K.P., 2013. Is market integration associated with informational efficiency of stock markets? Journal of Policy Modeling, 35(1), pp.29-44.

16. Horta, P., Lagoa, S. and Martins, L., 2014. The impact of the 2008 and 2010 financial crises on the Hurst exponents of international stock markets: Implications for efficiency and contagion. International Review of Financial Analysis, 35, pp.140-153.

17. Hull, M. and McGroarty, F., 2014. Do emerging markets become more efficient as they develop? Long memory persistence in equity indices. Emerging Markets Review, 18, pp.45-61.

18. Kristoufek, L., 2012. Fractal markets hypothesis and the global financial crisis: scaling, investment, horizons and liquidity. Advances in Complex Systems, 15(6). 10.1142/So219525912500658.

19. Kristoufek, L. and Vosvrda, M., 2013. Measuring capital market efficiency: Global and local correlations structure. Physica A, 392, pp.184-193.

20. Lane, P. and Milesi-Ferretti, M., 2007. The External Wealth of Nations, Mark II: Revised and Extended Estimates of Foreign Assets and Liabilities, 1970-2004. Journal of International Economics, 73, pp.223-250.

21. Lim, K.P. and Brooks, R.D., 2011. The evolution of stock market efficiency over time: a survey of the empirical literature. Journal of Economic Surveys, 25(1), pp.69-108.

22. Lim, K.P. and Kim, J.H., 2011. Trade openness and the informational efficiency of emerging stock markets. Economic Modelling, 28, pp.2228-2238.

23. Lo, A.W., 1991. Long-Term Memory in Stock Market Prices. Econometrica, 59(5), pp.1279-1313.

24. Mandelbrot, B.B. and Van Ness, J.W., 1968. Fractional Brownian motions, fractional noises and applications. SIAM Review, 10, pp.422-437.

25. Petersen, M., 2009. Estimating standard errors in finance panel data sets: comparing approaches. Review of Financial Studies, 22, pp.435-480.

26. Pukthuanthong, K. and Roll, R., 2009. Global Market Integration: An Alternative Measure and its Application. Journal of Financial Economics, 94, pp.214-232. 